\title{
The Construction of National(ist) SubJECt: Applying the IdeAs of Louis Althusser and Michel Foucault to Nationalism*
}

\author{
IEVA ZAKE \\ Amherst, University of Massachusetts
}

The article proposes a theoretical approach that analyzes nationalist ideologies as forces creating unique subjectivities. Such a perspective develops from combining Louis Althusser's ideas about ideology and Ideological State Apparatuses with Michel Foucault's insights on modern bio-power. It is suggested that the core of any nationalism is its political construction of subjective consciousness and body. With illustrations from mainly European nationalisms, it is reflected that there is a recognizable set of methods that most nationalist ideologies use to form their subjects. They construct, on the one hand, "national consciousness" by inventing national history, language and culture, and, on the other, "national body" using modern scientific knowledge about individuals and populations. In the end, the article suggests a new definition of nationalism that could be used in future empirical research.

\section{Introduction}

Nationalism has been one of the dominant ideologies of the $20^{\text {th }}$ century and continues to drive political movements and conflicts

* I would like to thank Prof. Gerald Platt for his help in writing this article. 
today. Most of the studies of nationalism have focused on it as a collective character, while the understanding of its subjective meanings has remained less clear. This article analyzes nationalist ideologies perpetuated by movements, political parties, state institutions and intellectuals as forces creating particular national(ist) subjects, that is, the identities of those who "belong," who embody the nationalist ideal and carry out nationalist projects. The present analysis shows that nationalist subjectivities are built on multi-layered inclusions, exclusions and intended to reproduce nationalist politics. Similarly to Barbara Cruikshank’s suggestion that the democratic citizen is an "effect and an instrument of political power rather than simply a participant in politics" (1999:5), I argue that the nationalist subject is both a product and a tool of nationalism.

Generally, I agree with the perspectives that identify nationalism as an ideology or doctrine that promotes a collective, unified and specifically ethnic (national) consciousness and identity (see, for example, Berlin 1979; Anderson 1993). However, I expand these approaches by emphasizing that any nationalism is intrinsically concerned with developing a conception of a particular "ethnic" subject. I illustrate this with examples from ideologies and policies of mostly European nationalist movements, groups or governments. ${ }^{1}$

The importance of the present analysis is in theorizing the creation of the national subject(ivity) using perspectives that have not been employed to study nationalism before, but have significant theoretical advantages to offer. Specifically, I employ certain elements of the wide theoretical perspectives of Louis Althusser and Michel Foucault. I focus upon their suggestions about modern power and ideology such as Althusser's writings on the Ideological State Apparatuses (ISAs) and Michel Foucault's conception of biopower, and use them for analyzing the "drama" of self-hood in nationalism. 
According to both Althusser and Foucault, the central elements of modern power are the workings of subjectification or the subject formation. This aspect differentiates modern power from earlier structural conceptions of political and social control. For Althusser and Foucault modern power creates its subjects, their identity and political freedom. Power maintains itself, while making subjects unable to articulate themselves outside the realm of power that constitutes them. In this respect, Althusser develops the notion of Ideological State Apparatuses (1971), which organize social life so that the dominant ideology can create subjects who reproduce the social order. ISAs achieve this goal by constructing subjective consciousness through socialization and interpellation. Subjective consciousness therefore is both a product and a guarantee of the power structure. This approach to the role of ideology in political power system can be very useful for understanding the workings of nationalism.

Foucault offers another powerful analytic tool-the concept of bio-power, which can be employed in analyzing the bodily aspects of subject formation. Foucault argues that modern power is based on scientific and expert knowledge about individuals as both social and biological beings. Modern forms of governmentality employ this knowledge to administer, manage and control the population. Therefore, as Foucault suggests, the development of modern science must be studied in conjunction with the changing forms and purposes of power. This insight enables me to argue that scientific knowledge has been and still is today also an important part of nationalist bio-power.

Althusser and Foucault provide insights in the ways that ideological institutions, socialization of individuals and knowledge production are all important techniques of modern power. Taken together, their work can be used to argue that expert knowledge, ideology and the institutions of their production create both consciousness and body of the national(ist) self-hood, too. Modern power in nationalism institutionalizes knowledge about natural and social 
reality, and uses various research institutions, universities and intellectuals as tools of social order. In general, although the theoretical constructs of the formation of subjective consciousness and body were not discussed in relation to nationalism in the original contexts of Althusser and Foucault's writings, my approach indicates that they are useful for explicating the workings of modern nationalist power.

However, it must be noted that my analysis of nationalism should not be understood as a suggestion that individuals are agency-less instruments in the hands of nationalists. I approach nationalism primarily as an ideologically driven process of subject formation with significant universal techniques. I suggest that all nationalist movements develop a particular project of national subjectivity, which they use to justify and promote their political agendas. This project contains particular methods of creating subjects' consciousness and body, which I intend to discuss here. Whether and how people accept or resist these nationalist conceptions of subjectivity is an issue beyond the scope of the present analysis.

In sum, I outline an approach that points our attention to a considerably generalizable set of methods that most nationalist ideologies use to form their subjects. However, I do not argue that every nationalist ideology employs all of the discussed techniques. Rather, nationalisms tend to "pick and choose" among the various methods - some are more "popular" than others and analyzing these choices might allow us to highlight important differences among various nationalisms. Here, I offer an analysis of the more widespread techniques of nationalist subject formation, which, in fact, could be used for further more extensive and comparative empirical investigations of various nationalist ideologies and policies. Overall, the study of the subject creation is one of the most important routes to a better understanding of individual and mass-level appeals of nationalism both in the past and today. 
The argument proceeds as follows. First, using Althusser's ideas about the role of ideology and ISAs in interpellating the subject and creating its "lived experience" I analyze how nationalist ideologies build national(ist) subjective consciousness. This process consists of three inventions - shared historical memory, common language and unique culture. Second, I turn to Foucault's analysis of bio-power as the creation of embodied subjectivity, and apply it to nationalism. I conclude with suggestions about a definition of nationalism from the perspective of subject creation as developed here.

\section{Construction of the national(ist) subjective consciousness}

According to Louis Althusser (1971), such modern power systems as capitalism require skilled, motivated, well-organized and controllable subjects that will reproduce the system of production itself. Therefore individuals are continuously learning and being taught throughout their lives not only the "rules of good behavior" (132), but also certain attitudes, manners, moral values, civic and professional conscience which will then enable them to respect, accept and promote the existing socio-economic order. In modern social systems, it is the function of dominant ideology and its apparatuses to directly produce such a socially organized (constructed) subjective consciousness. These Althusserian insights about the role of ideology also help to understand the process of subject formation in nationalism.

According to his analysis, ideology provides an "imaginary form of existence," (153) which functions as means of interpretation of both collective and subjective lived experiences. Althusser claims that ideology and its state apparatuses (ISAs) are aimed at producing such conceptions of self-identity as a sense of unique consciousness, interpretations of experiences as authentic and meaningful, individual beliefs and voluntary actions. Modern ideological apparatuses transform individuals into subjects of particular political, social and economic systems in which these 
subjects then function freely, self-efficiently and autonomously. Individual selfhood itself is a product of particular ideology, which continuously provides both cognitive and experiential meanings for individuals.

Therefore, according to Althusser, individual subjectivity must be understood only through an analysis of ideological techniques of consciousness formation used by the modern state power. The subject itself is a unique tool of modern state power. The subject as such "materializes" or becomes real to oneself and others only through the process of being "subjectified" by ideologically governed institutions of modern power - Ideological State Apparatuses (ISAs). At the same time, neither ideology, nor ISAs exist without seemingly autonomous, but constructed subjects that ensure their power (170).

This description shows modern power as an all-encompassing system of regulation and discipline, which surpasses any previous forms of social control. However, how concretely are individuals created as subjects with particular consciousness? There are two main stages in this process - first, the life-long socialization carried out by diverse ISAs; and second, what Althusser calls the "interpellation" - an ideologically organized way in which power addresses individuals as free and "real” subjects.

Louis Althusser lists a number of ISAs that all contribute to the socialization of individuals into becoming subjects - religious and educational institutions, the family, legal system, political organizations, trade-unions, mass media, the arts, literature and even sports (143). The socialization of subjects starts from the family, school, and ends with individuals enjoying literature or participating in trade-unions. The educational process is executed by ISAs according to the demands of the dominant ideology and the interests of the existing social order. By incorporating whatever various ISAs teach them cognitively, morally, experientially and emotionally, individuals develop a type of consciousness that 
enables them to function as full members and self-identify as "real" subjects in a given modern system of power system.

However, the process of subject formation does not end with socialization. The next significant stage is what Althusser calls "interpellation" or the way in which ideology and thus, the state power address individuals as free and autonomous subjects, not mere brain-washed subordinates: "the individual is interpellated as a (free) subject in order that he shall submit freely to the commandments of the Subject, i.e., in order that he shall (freely) accept his subjection. ... There are no subjects except by and for their subjection” (182). In the process of interpellation ideology and its institutions "hail" or literally call socialized individuals into being as true subjects of the power system. ISAs here treat individuals as subjects with a unique sense of personhood and identity, which results in individuals accepting themselves as subjects of power entitled with ideas of free choice, attitudes, and beliefs. Interpellation means matching individuals' sense of personhood with ideologically determined and shaped category of "subject.” By developing a sense of unique subjectivity individuals achieve the highest level of integration into the power system.

In sum, first, power system socializes individuals' consciousness through an extensive system of ISAs. Then, the new subjects are continuously "brought into existence" and reproduced as unique and free personalities by responding to the diverse calls of the ideology and power. The ultimate result is subjects who define and identify themselves cognitively, emotionally and experientially with the ways that power addresses them. ISAs play the most important role in this complex process of subject formation. They provide the justification and explanation to the rituals of power, socialize individuals personally and directly, create subjective consciousness, enable individuals to identify with the subjectidentity created by the power system, and finally they give moral and emotional meanings to individuals' lived experiences as real, authentic, individually unique and appropriate. This analysis of 
ISAs offered by Althusser is very useful for understanding how the power of nationalist ideology works too. In nationalism, individuals are interpellated through a complex ideological mechanism in which they come to believe that they are truly liberated and autonomous if they identify with particular national subjectivity. The nationalist ideology works to convince individuals of the presence and reality of a unique national identity and then “calls on” (interpellates) individuals to demonstrate and possibly even act voluntarily in the name of this identity.

It must be noted that in this Althusserian conception and its application of nationalism, ideology is not a mere "evil" force used by the dominant groups to force people into subjection. Rather in any modern social order ideology provides the connection between concrete individuals and the social, economic and political system as real, correct and authentic to them. It is a force enabling individuals to live in a shared social reality. It is equally necessary for both dominant and subordinated groups because it interprets groups' experiences and relates them to their particular social positions. Both dominant and subordinated groups develop their consciousness through the same ideology. For example, nationalist ideologies enable different groups to co-exist and even co-operate in the same social framework. Thus, in nationalist politics elites can see themselves as executing a historical project of national liberation, while subordinated groups can interpret themselves as important agents of social change.

It must be noted that, of course, Althusser himself was primarily interested in the ways that the capitalism is maintained and reproduced by an ideology that justifies class society, therefore he viewed the ideology of national consciousness as solely a tool for capitalist exploitation (155). However, I suggest that his framework for analyzing the subject formation as discussed above can be effectively applied to the nationalist ideology for its own sake and not as merely serving the interests of capitalist production. Not all nationalisms can and should be understood in the context of 
capitalism as many socialist movements and states use nationalist ideologies (Gregor 2000).

More concretely, nationalist ideologies usually employ differing combinations of the three following techniques of subject formation or three "inventions": 1) the invention of ethnic history and national memory; 2) the invention and preservation of national language; and 3) the invention of substantially different national/ ethnic culture. All these methods are used in order to create the consciousness of national subjects. These techniques constitute the cognitive, moral and also emotional standard for the national subject as a concrete individual who knows the history, understands and speaks the national language, and practices the national culture.

In the process of constructing the national(ist) consciousness, ideologies invent and maintain the standards of common history, language and culture. This proceeds as follows - first, individuals are socialized into national identity through learning the true history, practicing the authentic culture and speaking the correct national language. This develops their national consciousness. Then, these individuals are interpellated as national subjects so that they interpret their lives merely within the context of the national group, and become ready to act in the name of asserting and protecting its history, language and culture. Individuals become national subjects when they are able to reproduce nationalist principles freely and autonomously. Thus, national subjects are those who feel completely comfortable in the world shaped and reproduced by various nationalist ISAs, and who experience their existence as authentic within the frames of nationalist ideology. Therefore these subjects also view everybody else as having essentially different consciousness, which then serves to explain and justify nationalist conflicts and a sense of threat. 
The three ideological tools of invented history, language and culture are institutionalized and realized by particular Ideological State Apparatuses. The experts working at the ISAs develop a definition of the national subject and prescribe what concrete individuals must do in order to become an integral part of a national community, to have a national identity and thus - to be real subjects with real national experiences. In the following, I will analyze in greater detail each of the three methods.

\section{The invention of national history}

The invention of national history and memory has proved to be one of the most successful nationalist tools in creating subjects and interpellating them. In most cases, national history is an ideological invention intended to construct selfhood with a sense of shared collective memory and heritage. It is a "retrospective illusion," which consists of believing that "the generations which succeed one another over centuries on a reasonably stable territory, under a reasonably univocal designation, have handed down to each other an invariant (historical) substance” (Balibar 1991:86). At the same time, historical narratives also are intended to make subjects see themselves as the culmination of a united, single process of national development (Balibar 1991; Alonso 1994). Thus, the selective and invented historical narratives enable subjects to rationalize time as a mythical development of the nation and themselves in relation to it (Alonso 1994). In Northern Europe, this process of creating sacral, national time was embodied in the invention of heroic epics such as "Kalevala" for Estonians and Finns or "Lachplesis" for Latvians. These fictional documentations of the achievements of mythical national heroes later were used to characterize all national subjects and their "mentality."

In Europe the process of inventing national history reached its peak during the $19^{\text {th }}$ century. It was practiced by the old nations as much as by the newer ones. Usually it was an ideological project necessary to justify the establishment of nation-states as advocated by the growing strata of nationalist middle class intellectuals 
(Gellner 1983; Hroch 1996). One of the central goals of this ideological enterprise of national history invention was to outline identifiable features of the folk. National history was to reflect the standard for building both collective and subjective identities as inherited from "the beginning of time." The national past was and is documented by nationalists similarly to how maps and territorial shapes are used as essential representations, even embodiments of a particular nation or ethnic group (Biggs 1999).

The historical standard of identity was based on the notions of continuous tradition. Andrew Lass' (1988) research on the $19^{\text {th }}$ century Czech manuscript forgery demonstrates how the fake historical texts inspired a production of cultural monuments. This was a nationalist attempt to create a unique national tradition, which later served as a meaning-giving context for the everyday life of national(ized) subjects. According to Lass, national history, as concretized in monuments, historical relics, books and pictorial illustrations created the "real" national(ized) world outside the person and made this historical world "lived" and moreover "livable." The invention of national history thus was also an invention of tradition with its various normative principles expressed in tales, stories, events and symbols.

Further, in Eastern and Central Europe the invented national history and tradition prioritize the peasant roots of the contemporary nations. Moreover, the peasant life-style is treated as the most authentic way of living out one's national identity, tradition and history. Thus, during the early days of the movement for Latvia's independence from the Soviet Union in the late 1980s one of the most popular nationalist slogans was "We, Latvians, are a people of ploughmen!” This was an attempt to evoke the authentic Latvian roots in peasantry as incompatible with the industrialized reality of Soviet Latvia. It was argued that the Soviet modernization has destroyed the authentic, particularly Latvian peasant life-style. Latvian nationalists used the historical narratives about peasants as a symbolic standard and embodiment of the national subjectivity 
and its consciousness. Moreover, nationalists institutionalized these ideas in a number of ISAs which developed policies that, first, encouraged Latvians to become farmers and then institutionalized state subsidies as well as tax cuts for them. Thus, national history and the tradition were used to provide certain entitled individuals with a context for building their nationalist consciousness.

These elements (the collective memory, heroes, real and fake documents, shared destiny, tradition, national life-style, etc.) were and still are produced by a number of "history ISAs" such as national Academies of Science, History Institutions and history classes at schools. They ensure that the national history serves as the basis of subjective national consciousness and produces "a relation between that which supposedly occurred in the past and the present state of affairs” (Friedman 1992: 837). Unsurprisingly, the development of the history-producing ISAs has often reflected their mission. In many cases, the selection of the "the right" people for doing the job of historical research has been at the center of heated nationalist debates. For example, in Russia during the $18^{\text {th }}$ and $19^{\text {th }}$ centuries, the growing Russian nationalist elites were expressing constant dissatisfaction with the descriptions of Russia's past by non-Russian historians (Rogger 1960). It was continuously stressed that foreign historians do not appreciate the glory of Russia's achievements and are essentially prejudiced, and that Russian historians are absolutely necessary to write the "true" history.

In general, the main task of the historical ISAs is provide and preserve the "correct" version of national history which can be taught in schools, ritualistically re-produced in national holidays and re-invented in national symbols such as the national flag, the anthem, etc. The concern with which these ISAs work is due to their importance in creating the national subjectivity. National history and tradition is an identity frame, available narrative or, as Jonathan Friedman (1992) calls it "a meaningful universe of events and narratives"(838) necessary for the "nationalization" of each 
individual. They enable individuals to define the present social world as non-coincidental, historically rooted and authentic. Then, as Miroslav Hroch (1993) suggests, the memory of the shared national past can become the destiny of the group and individuals comprising it.

In this sense the nationalist use of history works as subject interpellation. Subjectivity is produced (or interpellated) in relation to a collective past, which determines and explains the present and future. National subjects search for important points of guidance in the national history and become motivated to make important, nationalist choices about today's politics. The institutions that reproduce the national history in school lessons and textbooks, in research institutions and universities, as well in the nationalist organization of social time and space around memorial days and national monuments, assert that the nation and its subjects are "truly" real. The history-producing ISAs must not only create a stable society and state, or establish the dominance of an elite group. Instead, as Althusser's analysis would suggest here, the ISAs producing national(ist) history are aimed at creating a distinct and unique national subjective consciousness, which is enhanced with a sense of roots, embedded in notions of historically continuous identity and national future aspirations.

\section{The invention of national language}

The next technique of forming the national consciousness is the invention and institutionalization of national (state) language. The national subject is essentially produced along with designating its authentic language. Benedict Anderson's research (1993) demonstrates how crucial for the national imagined communities in Europe was the crystallization of one dialect as the national language. He emphasizes the role of printing capitalism in developing the national languages from what he terms "printlanguages," that is, accidentally chosen dialects, which became 
mechanically reproduced, syntaxed and grammaticized standards for European national languages.

Anderson's analysis questions assumptions that national languages are consistent and historically inherited cultural essences of ethnic groups, instead showing that national languages are products of concrete historical circumstances. Printed languages enabled the creation of unified fields of exchange and communication between people who were speaking widely diverse vernaculars. This gave a new fixity to the printed dialect to the extent that it could later serve in the nationalist projects of homogenizing the national consciousness. Privileging one vernacular and transforming it into the printed language not only eradicated other vernaculars, but also constructed a linguistic standard, which in turn enabled nationalists to create ISAs that could both socialize and regulate (interpellate) the speakers and their consciousness.

If, as Anderson shows, the selection of national languages was a more or less coincidental process, then the next stage - the invention of a native speaker and their linguistic rights is already an ideologically planned project performed by well-organized ISAs. National(ist) ideologies usually are very concerned with the preservation of "pure” national languages. Often one of the central claims of nationalist movements is that the unique ethnic language is "endangered" and requires special protective efforts in which case they push local governments to establish, for example, "Language Police" (as in a number of post-Communist Eastern European countries). In other cases, nationalist movements evoke notions of language rights as human rights to be included in national and international legal documents (Woolard and Schieffelin 1994).

Such ideological assertions often lead to massive language planning policies, for example, bureaucratically organized procedures for standartizing and enforcing the correct use of language or creating teaching centers for non-speakers and immigrants. These language protection projects always have two goals. On the one hand, they 
are cultural projects of documenting language with an aim to create a normative standard. On the other hand, they are attempts to create a particularly organized consciousness of its speakers who would identify themselves through the use of this language. The "ideal" result of nationalist language politics is a consciousness similar to what the Irish poet Nuala Ni Dhomhnaill describes when she explains the reasons for choosing to write in Gaelic: "at some very deep level, the language had chosen me. If there is a level to our being that the want of any other word for it I might call 'soul' (I believe there is), then for some reason that I can never understand, the language that my soul speaks, and the place it comes from, is Irish" (1995:3). Similarly, the early $18^{\text {th }}$ century Slavophiles argued that Russian elite is polluting its consciousness or soul by using French (Rogger 1960). Early Russian nationalists, such as Karamzin and Shishkov argued that the new generation not only speaks French, but also becomes French. They wanted their countrymen to stop speaking French and, importantly, to stop thinking in French and use Russian as the language of "honesty and freedom." Such arguments clearly show the link between subjective consciousness, lived experience and national language in nationalist rhetoric.

History shows that in order to produce subjects that both speak and think in the national language, a number of ISAs need to be created. In the same $18^{\text {th }}$ century Russia, for example, the Empress Catherine established a particular institution of Free Russian Assembly aimed at the study, normalization, grammatical ordering and fixing of the Russian language (Rogger 1960). The major task of this ISA was to publish a grammar and a dictionary, and set a standard for using Russian in bureaucratic and administrative matters. Clearly, this was a political enterprise based on growing political nationalist sentiments and aimed at asserting Russia's claims to international respect.

Also, one of the central political projects of the modern Basque nationalist movement was not only recovering the disappearing 
Basque language, but also literal increasing of the number of its speakers in the 1980s (Urla 1988). This was achieved by setting up a number of ISAs such as state administered language-training programs and courses intended not only to teach the language, but also to enlarge its public presence. Such procedures, on the one hand, created the correct (teachable) version of Basque, while, on the other hand, homogenized and unified its speakers. These ISAs interpellated the socialized subjects as "national speakers." Similarly, the Catalonians since 1993 have attempted to increase the amount of compulsory teaching in Catalan that is offered in their schools (Mar-Molinero 1996). The speakers of such ideologically "protected" languages are subjects interpellated into national consciousness through various language ISAs. These ISAs are organized around the needs of the nationalist ideology to reproduce itself by shaping the consciousness of "native speakers" or national subjects.

Such institutions and policies do not treat national language as a mere "cultural value” or "symbol” (Mar-Molinero 1996). Rather, language becomes an instrument of subject formation and homogenization. For example, in post-Communist Latvia, the integration of non-Latvians, according to Latvian nationalists, had to focus primarily on two aspects - teaching the history and the Latvian language. Here and in other similar cases, the mastering of national language is viewed as a necessary precondition for maintaining homogeneous communication within the community (Hroch 1993). In some cases the state bureaucracies can even set out to control the regularity of national language use in the mass media, while other apparatuses hire professional linguists to invent "native" words and regularly inform the public about the correct ways of speaking.

Again, these procedures are less important for the preservation of language as a cultural value per se. Instead, they perform ideologically based and often state administered rituals of production of national subjects, who can later be interpellated as 
real, autonomous and self-motivated by addressing them in the national language. As individuals become the "carriers" of the national language they also become able to assert that they experience the world through this language. This is an essential goal of any nationalist ideology. As a result, these national subjects become increasingly vulnerable to the manipulations and interpellations of nationalism as it can call them to radical, even violent actions in the name of protecting language rights as their human rights. Most of the language preservation practices are basically ideologically driven procedures that define the parameters of the subjective and national "lived experience." Through language and its regulated use subjects become both products and tools of nationalism.

\section{The invention of substantially different national culture}

The last of the more popular nationalist techniques, which can be illuminated by applying Althusserian ideas of the ideological socialization and interpellation of the subject, is the substantialization of national culture. By it I mean the transformation of cultural practices into politicized, materialized and institutionalized embodiments of a national essence. It takes place when cultural products such as folk-tales, images, metaphors, etc. are turned into the substantial representations of national essence. They materialize in the collections of folk songs and fairy tales, TV programs, song and dance festivals, descriptions of national character and political slogans. In this process, cultural practices and products are re-interpreted in the context of national identity as manifestations of uniqueness of the ethnic group or nation. Nationalist ideologies invent national culture and its distinctiveness in order to create a particularly national(ized) environment of experience. This environment then serves as the interpretative base for the national subject - the realm of its authentically national existence. 
In general, by asserting that there is a unique national essence expressed in its culture, nationalists are implicitly making claims about the essential features and consciousness of those practicing and consuming it. One's national consciousness is measured against their ability to practice the national culture. In the environment of substantialized national culture, individuals' current experiences are directly linked to materialized national heritage expressed in holidays, customs, items of consumption, music, art, literature, even manners of behavior and speech. National culture becomes an intrinsic part of the individuals' everyday life, which in turn constructs their consciousness and even makes them accountable to the nationalist agendas. One such everyday substantialization can be found in the practices of family and kinship.

In most nationalist ideologies, family is treated as an ultimate embodiment of the nation, its values, behavior and its need for inter-generational transmission of the national heritage. Of course, the family is also important to nationalists as the instrument that literally reproduces the nation (this makes it also a tool of nationalist bio-power, which I intend to discuss later). Here, I emphasize the role of family as the ISA in which national culture is literally transformed into practices and rituals that shape consciousness of national subjects. In many nationalist ideologies family is characterized as the source of national unity, purity and cultural uniqueness. This explains the emphasis put on its stability and sanctity. In the case of post-Soviet nationalism in Russia and the former Soviet republics, new legislators liquidated kindergartens and "renovated" the nation by forcing women to stay home to take care of children. At the same time, by interpreting carefully selected national holidays into family events and organizing nationalist celebrations for the whole family, nationalists grant family the responsibility for continuous re-production of national culture.

Also, nationalist ideologies often use traditional family-based gender roles as a precondition for preservation and transmission of national culture. Familial gender roles are translated into 
"natural" justifications for nationalist power distribution as in, for example, keeping women or homosexuals out of politics. Maxine Molyneux (quoted in Mostov 1999) argues that in the postcommunist political contexts, conservative nationalist ideologies seek to use the family to authorize a variety of controls over women. She writes: "A woman's 'duty' is described in terms of 'supporting her man,' 'serving her nation' and in effect, surrendering her own interests to the cause" (57). Nationalist ideologies use traditional family as the basis of the nation's unique character and its claims for political power. By practicing familial gender norms, men and women transform themselves into active national subjects who perform national culture in their everyday lives.

Family structures not only the power relations, but also subjective consciousness of those involved in political struggles (Yuval-Davis 1998). In nationalist contexts family can be used as a tool that interpellates (organizes and motivates) subjects as not just members of their families, but participants in the national family that may need to be defended and fought for. Family as an ISA re-produces national identities, norms of heterosexuality and institutionalized gender roles in order to socialize individuals as national subjects who then think of their familial position as a responsibility in preserving the national culture.

Another important element in this technique of substantializing or essentializing national culture is the development of enthusiastic descriptions of so called "national character.” It is a popular method of political selection and careful construction of national consciousness. Of course, the most horrible application of this technique was the Nazi propagation of national culture as a set of essential characteristics embodied in concrete individuals. There are other, less dangerous nationalists uses of essentialized culture. Thus, Russian nationalism for centuries has been struggling to define the particular features of the national character of the Russians as opposed to the Westerners. In the $18^{\text {th }}$ century, for example, such intellectuals as the Princess Dashkova, Karamzin 
and Scherbatov wrote a number of "studies" in which they characterized Russianess as being simple, unspoiled, straightforward and honest, loyal and God-fearing (Rogger 1960). Continuously over time various Russian intellectuals have added new cultural features such as genuine sensibility, generous soul, warmth, friendship, spontaneity or feeling and behavior to the portrait of the essential national subject. The goal, of course, of these nationalist "descriptions" has been not only to mark Russians off from other peoples, but also to argue that there is something uniquely natural and authentic about Russianess. This substantializing of culture in the "national type" is always ideologically driven and very selective about the cultural products, traditions and practices it admits.

The inventions of national family or ideas of national character as an "essential manifestation" of a unique culture can be institutionalized in various ISAs. The family itself can serve as a state-supervised process of subject formation. Similarly, various cultural practices and norms can be identified as true reflections of the national consciousness and thereby politically promoted, supported, taught and ritualized. Following Althusser's suggestions, it is possible to see that nationalism can transform ideas of cultural difference into apparatuses that socialize individuals and then interpellate them as national subjects. More concretely, national culture and character in become something that can be taught, prescribed and used to describe individuals to the extent that they become the carriers of national difference and as such can be motivated and used for political struggles.

In sum, my Althusserian-based analysis suggests that nationalist ideologies socialize and then interpellate their subjects by inventing national history, generating national language and institutionalizing selected, "essential” features of national culture. These inventions gain their power through a number of ISAs that are governed by an ideological goal of delineating and reproducing the national(ized) subjective consciousness. This consciousness 
contains carefully selected historical past, standardized version of national language and correct cultural practices, behaviors and even personal features. The subjects are socialized into this consciousness by ISAs that are governed by the dominant ideology, which then becomes indispensable for the subjects. They need it to interpret their lives as "lived experiences" of uniquely national subjects. Finally, this new consciousness is "called into existence” or interpellated through nationalist politics such as struggles for independence, ethnic conflicts or policies of discrimination.

\section{The construction of "national(ized)" body}

Apart from the interest in subjective consciousness, nationalist ideologies are also concerned about the material, bodily aspects of national subjects. Nationalism often extends its power to constructing the parameters of a "national body." It is an ideologically based political process of interpreting and treating national belonging as a literal aspect of human bodies. Thus, nationalism may not only metaphorically describe nation as an organism, but also directly identify nation as a collective of purely national bodies. In the following I focus on the methods used in nationalisms' concerns with preserving and maintaining the embodiment of the nation. Here the role of scientific knowledge about human body becomes the crucial tool. In this context, Michel Foucault's theory on modern bio-power is very helpful. It provides important insights that could be applied to the cooperation between power and knowledge in the context of nationalism's construction of the well-disciplined bodies of national subjects.

Foucault asserts that modern power works by replacing coercion with subtle control of self-discipline and self-surveillance. When analyzing the modern power systems, he discusses the meaning and social implications of Panopticon - the modern prison based on the principle of constant surveillance and consequent internalization of guard's gaze by the inmate. To Foucault, the Panopticon represents the foundation of the modern power - its 
non-coercive surveillance that creates self-disciplined and docile subjects (bodies). Thus, power's regulations become integral parts of subjects' everyday existence (1977; 1972; 1983). This is a highly rational and scientific type of power that effectively serves the interests of the modern state.

The state uses and actively promotes scientific knowledge as one of its power instruments. Individuals in the modern society are objects of various types of scientific inquiry (which usually is closely linked to the needs of administrative power institutions), and at the same time they are expected to employ the expert knowledge to discipline themselves. Foucault argued that through the development of human sciences, "Western man was gradually learning what it meant to be a living species in a living world, to have a body, conditions of existence, probabilities of life, an individual and collective welfare" (1978:142). Modern power used these aspects of scientific development and created scientifically organized institutions of administration using the available information about human bodies. The aim of these institutions and this type of governmentality is to produce subjects who are administered, surveyed and surveying themselves according to rational and scientifically proven guidelines. It creates new types of people who have internalized the scientific knowledge about themselves and thus freely obey power's control through selfdiscipline.

This Foucauldian approach to modern power is useful for analyzing nationalism, too. Ideological projects of creating "national" subjectivity are often based on the scientific knowledge about the individual body. For example, historically, the development of such disciplines as criminology and social administration helped to invent the subjects to be "administered." I suggest that the development of science in general was and still is deeply connected to political invention of subjects to administer through their embodiment, biological features, blood-types and DNA codes. The human sciences in the $18^{\text {th }}$ and $19^{\text {th }}$ centuries created 
conceptualizations of the human body and psyche, which were used for nationalist political projects such as writing the national laws on citizenship, property rights, meaning of the family and immigration legislation.

According to Foucault, this process of politicizing the human body contains two aspects. First, the "anatomo-politics" of the human body, which included such scientifically based and administratively important aspects as self-discipline, the medicalization of birth, death and reproduction, notions of individuals' health, nutrition, diets, cults of exercising, etc. The second aspect of modern politicizing of the body was bio-politics or bio-power (1978), which focuses on structuring the systems of public administration (including the calculation, counting, measuring and controlling population) around the issues of politically "subjectified” bodies. As I suggested earlier, the concept of bio-power is especially helpful in understanding how nationalist ideologies create national subjects.

Nationalisms often use bio-power to create various institutions such as the national family, schools, the army and police, individual medicine and hygiene, and administration of collective bodies. Unquestionably, one of the historically most threatening examples of this process was Nazi regime and its "scientific" projects regarding the bodies of national or non-national subjects. Today's nationalist uses of bio-power are manifested in the apparatuses that control immigration, institutionalize so-called jus sanguinis citizenship legislation and control reproduction. Concretely, these institutions place restrictions on the adoption of "national children" by foreigners, create regulations regarding children from ethnically mixed families, de-legalize gay and lesbian marriages and institute either the state subsidies to the families of more than two children (in the case of certain European nations, while in China, on the other hand, we see a prohibitive use of bio-power). 
Successful functioning of these institutions is made possible by their relationship to scientific and expert knowledge of various disciplines, especially, statistics, demography, medicine, human biology, public policy, physical anthropology, and in some cases also economics, political science and sociology. Modern bio-power combines the surveillance with scientific justifications for analyzing and learning about the human body. Therefore, in nationalist politics information provided by public health researchers, demographers and statisticians can serve as a basis for developing population policies, which favor certain groups at the expense of others. This leads to political decisions such as enforced sterilization or restrictions of the availability of reproductive technologies - all in the name of preserving the authentic "national body" (Bryan, Dadzie and Scafe 1985). In Croatia, following President Tudjman's initiative for a "spiritual renewal of the nation," the government established the Ministry of Renewal with the special Department of Demographic Renewal. The aim of this institution was to work out a scientifically based program for an "ethnically pure" birthrate in Croatia (Mostov 1999:56).

Undoubtedly, the development of the modern systems of knowledge such as anthropology, sociology, economics, biology, statistics, medicine, etc. enabled the state power to discover and start administering its new subject - "the population" - from the late $18^{\text {th }}$ and early $19^{\text {th }}$ century on (Foucault $1972 ; 1983$ ). The goal of the modern state administration has been to create effective procedures to meet and regulate the needs of this population and its elements - individuals. In this sense, the whole modern statehood and welfare state in particular can be viewed as a form of scientifically based "therapy" to its population.

Even though all states took advantage of scientific developments, the nationalist ideologies and institutions have been some of the most eager consumers of scientific rationalizations, data and conclusions. Excellent examples of this are the connections 
between the development of anthropology, biology, physiognomy and political interest in defining the racial and ethnic differences among human bodies. It has been demonstrated that most of the projects in measuring and calculating the shapes of human bodies in the $19^{\text {th }}$ century were primarily motivated by colonial and nationalist interests of the new European nations and their attempts to define themselves as different and superior to the foreign Other (Haller 1971). Similarly, the enthusiastic biological, medical and anthropological study of non-white women such as those performed on the famous Sarah Bartmann in the $19^{\text {th }}$ century was a part not only of the scientific project of cataloguing and classifying all the living creatures, but also the European national and economic expansion in the world (Fausto-Sterling 1995).

The links between nationalism and scientific knowledge are important today as well. Especially, disciplines of social measuring such as demography and statistics have become influential tools of nationalist bio-power. In Serbia during the post-communist nationalist period demographers became involved in the nationalist project of counting the number of years it would take for the Serbian nation to disappear if the birth rates did not increase and drawing up a bill threatening to limit women's rights to abortion (Morokvasic 1998; Djuric 1995). The scientifically based analyses of the causes and solutions to the so-called "white plague of low birthrates" have been a theme of the state controlled newspapers throughout the former Yugoslavia (Mostov 1999).

Further, Jacqueline Urla (1993) demonstrates how in the case of Basque nationalists justify their political strategies and demands by employing the public surveys and census data - the scientifically collected and organized "body count." The statistical information about the numbers of Basque speakers or Basque national subjects allows nationalists to create an ideological construct of "the nation at risk" with clear biological references. Nationalists produce numerous maps, diagrams and illustrations using the statistical data to show the threatening tendencies in the number of Basque 
"bodies" and mobilize Basques and their supporters around these arguments of scientific experts.

Basque nationalists take advantage of the statistically defined concept of "who counts as a Basque" and identify with the numbers produced by statisticians and demographers in the counting of "Basque-speaking bodies." Nationalists interpret the scientific measurements of Basques as their political and essential national subjectivity. The counting of "Basque bodies" becomes a political statement about the need for nationalist politics. As Urla argues, the statistical modes of categorizing speakers and their linguistic skills introduce new forms of essentialized subjectivity with particular features of individual identity and responsibilities towards the larger social body of Basque community (1993:820). The next step is to make up a statistically proven statement that the essential subjects or the bodies of the nation are disappearing and are in need for special measures of protection. At this point the nationalist based population management and control institutions can legitimately implement their bio-power by instituting policies and organizations entirely dedicated to the preservation and expansion of essentially national bodies. Thus, the object of the scientific research and the subject of nationalist politics coincide.

Similarly, the icons of the scientific classification developed in the $18^{\text {th }}$ and $19^{\text {th }}$ century biological and human sciences became important elements in the nationalist projects of categorizing human bodies according to their ethnic origins and the degree of the "ethnic blood" in them (Ritvo 1997). Today, various bureaucratic forms and tables that are important parts of nationalist state power are essential replications of scientific systems of difference classification. Moreover, in both bureaucratic and scientific systems of categorization the knowledge about difference is turned into an instrument of population management. Knowing about the differences between people is a crucial part of the nationalist political projects. Nationalism politicizes the essentialized 
differences between the authentic and non-authentic bodies by creating such institutions as family legislation, immigration offices and regulations, welfare agencies. etc., and scientific classifications and rationalized descriptions of difference have been helpful in enabling nationalist ideologies to do this.

These intersections between the scientific knowledge and the nationalist ideologies lead to the creation of an embodied national subject. National subject and its body - classified, categorized and regulated - are both products and instruments of expert knowledge as it is accumulated and reproduced in various political and administrative institutions. Foucault's ideas about the modern bio-power and "governmentality" as the scientifically based administration of population enable us to see that nationalist ideological movements use bio-power in order to enforce the political notion of pure national embodiment. Nationalism not only uses modern expert knowledge; it has developed along with the growing scientific research and knowledge. Unsurprisingly, nationalist movements and states today are also interested in strengthening the scientific disciplines such a statistics, sociology, public administration, criminology etc., which are useful in the process of creating and administering the national subjects.

\section{Conclusion}

Nationalist ideology works through construction of both consciousness and body of its national(ized) subjects. Nationalism is not merely an ideological promotion of collective interests. It also targets and produces the two aspects of individual selfhood consciousness and embodiment. Subjective national consciousness is a product of a system of ISAs that invent national history, language and cultural identity, which are then used to socialize individuals and reproduce them as subjects who know, speak and practice the nation. The national body is regulated by rationalized 
administration of population (bio-power), which employs rational and scientific expert knowledge about individuals and their bodies. Both these projects of nationalism betray its trust in the role of the collective or state institutions. Most of nationalist movements today and in the past aimed to create a set of autonomous national institutions and later achieve independent statehood.

This leads me to the final task - an updated definition of nationalism. Within the context of my theoretical analysis, I suggest that nationalism needs to be approached as a political ideology, which enforces a concept of individuals as the ultimate carriers of national consciousness and embodiments of the nation. Individuals are nationalized, that is, constructed as essentially different from each other depending on being included or not in a particular national whole. This political assertion of national difference is ultimately aimed at establishing a system of administration, which is then put in charge of further refining and reproducing the crucial features of the consciousness and body of the national subjects.

\section{References}

Alonso, Ana M. 1994. "The Politics of Space, Time and Substance: State Formation, Nationalism and Ethnicity." Annual Review of Anthropology 23: 379-405.

Althusser, Louis. 1971. Lenin and Philosophy. New York: Monthly Review Press.

Anderson, Benedict. 1993. Imagined Communities. London: Verso.

Balibar, Etienne. 1991. "The Nation Form: History and Ideology.” In Race, Nation, Class: Ambiguous Identities, ed. Etienne Balibar and Immanuel Wallerstein, 96-106. London: Verso.

Berlin, Isaiah. 1979. Against the Current: Essays on the History of Ideas. New York: The Viking Press.

Biggs, Michael. 1999. "Putting the State on the Map: Cartography, Territory, and European State Formation.” Comparative Studies in Society and History 41: 374-405

Bryan, Beverly, Stella Dadzie and Suzzanne Scafe. 1985. The Heart of the Race: Black Women's Lives in Britain. London: Virago. 
Cruikshank, Barbara. 1999. The Will to Empower: Democratic Citizens and Other Subjects. Ithaca: Cornell University Press.

Dhomhnaill, Nuala N. 1995. "Why I choose to Write in Irish, The Corpse That Sits Up and Talks Back.” The New York Times Book Review January 8: 27-28.

Djuric, Tatjana T. 1995. "From National Economies to Nationalist Hysteria - Consequences for Women.” In Crossfires: Nationalism, Racism and Gender in Europe, ed. Helma Lutz, Ann Pheonix and Nira Yuval-Davis, 121-141. London: Pluto Press.

Hroch, Miroslav. 1996. "From National Movement to Fully Formed Nation: The Nation-Building Process in Europe.” In Becoming National, ed. Geoff Eley and Ronald Grigor Suny, 60-77. Oxford: Oxford University Press.

Fausto-Sterling Anne. 1995. "Gender, Race and Nation: The Comparative Anatomy of 'Hottentot' Women in Europe, 1815-1817.” In Deviant Bodies, ed. Jennifer Terry and Jacqueline Urla, 19-49, Bloomington: Indiana University Press.

Foucault, Michel. 1983. "The Subject and Power." In Beyond Structuralism and Hermeneutics, ed. Hubert L. Dreyfus and Paul Rabinow, 208-226. Chicago: University of Chicago Press.

- 1978. The History of Sexuality. New York: Vintage Books.

-1977. Discipline and Punish: The Birth of Prison. New York: Vintage Books.

—. 1972. Power/Knowledge, edited by Colin Gordon. New York: Pantheon.

- 1970. The Order of Things: An Archaeology of the Human Sciences. New York: Vintage Books.

Friedman, Jonathan. 1992. "The Past in the Future: History and the Politics of Identity.” American Anthropologist 94: 837-859.

Gellner, Ernest. 1983. Nations and Nationalism. Ithaca: Cornell University Press.

Gregor, James A. 2000. The Faces of Janus: Marxism and Fascism in the Twentieth Century. New Haven: Yale University Press.

Haller, John S. 1971. Outcasts from Evolution: Scientific Attitudes of Racial Inferiority 1859-1900. Carbondale: Southern Illinois University Press.

Lass, Andrew. 1988. "Romantic Documents and Political Monuments: The Meaning-Fulfillment of History in the $19^{\text {th }}$ Century Czech Nationalism.” American Ethnologist 15: 456-471. 
Mar-Molinero, Clare. 1996. "The Role of Language in Spanish NationBuilding.” In Nationalism and the Nation in the Iberian Peninsula, ed. Clare Mar-Molinero and Angel Smith, 67-89. Oxford: Berg.

Morokvasic, Maria. 1998. "The Logics of Exclusion: Nationalism, Sexism and the Yugoslav War.” In Gender, Ethnicity and Political Ideologies, ed. Nickie Charles and Helen Hintjens, 65-90. London: Routledge.

Mostov, Julie. 1999. "Women and the Radical Right: Ethnocracy and Body Politic.” In The Radical Right in Central and Eastern Europe since 1989, ed. Sabrina P.

Ramet, 49-63. University Park, Pennsylvania: The Pennsylvania State University Press.

Ritvo, Harriet. 1997. The Platypus and the Mermaid and Other Figments of the Classifying Imagination. Cambridge: Harvard University Press.

Rogger, Hans. 1960. National Consciousness in Eighteenth-Century Russia. Cambridge: Harvard University Press.

Urla, Jacqueline. 1993. "Cultural Politics at an Age of Statistics: Numbers, Nations and the Making of Basque Identity." American Ethnologist 20: 818-843.

—. 1988. "Ethnic Protest and Social Planning: A Look at Basque Language Revival.” Cultural Anthropology 3: 379-394.

Weeks, Theodore R. 1996. Nation and State in Late Imperial Russia: Nationalism and Russification on the Western Frontier, 1863-1914. DeKalb: Norther Illions University Press.

Woolard, Kathryn, and Bambi B. Schieffelin. 1994. "Language Ideology.” Annual Review of Anthropolgy 23: 55-82.

Yuval-Davis, Nira. 1998. "Beyond Differences: Women, Empowerment and Coalition Politics.” In Gender, Ethnicity and Political Ideologies, ed. Nickie Charles and Helen Hintjens, 168-189. London: Routledge.

\section{Note}

${ }^{1}$ Importantly, I am not making a precise distinction between nationalism as a political movement and "official" government nationalism as suggested by Theodore Weeks (1996). My approach primarily deals with nationalism as a general ideological force that materializes equally in both state policies and political movements. 